\title{
Schwann Cells: Development and Role in Nerve Repair
}

\author{
Kristján R. Jessen ${ }^{1}$, Rhona Mirsky ${ }^{1}$, and Alison C. Lloyd ${ }^{2}$ \\ ${ }^{1}$ Department of Cell and Developmental Biology, University College London, London WC1E 6BT, \\ United Kingdom \\ ${ }^{2}$ MRC Laboratory for Molecular Cell Biology, University College London, London WC1E 6BT, \\ United Kingdom \\ Correspondence: k.jessen@ucl.ac.uk
}

\begin{abstract}
Schwann cells develop from the neural crest in a well-defined sequence of events. This involves the formation of the Schwann cell precursor and immature Schwann cells, followed by the generation of the myelin and nonmyelin (Remak) cells of mature nerves. This review describes the signals that control the embryonic phase of this process and the organogenesis of peripheral nerves. We also discuss the phenotypic plasticity retained by mature Schwann cells, and explain why this unusual feature is central to the striking regenerative potential of the peripheral nervous system (PNS).
\end{abstract}

$T_{\text {celd }}^{\text {h }}$ he myelin and nonmyelin (Remak) Schwann cells of adult nerves originate from the neural crest in well-defined developmental steps (Fig. 1). This review focuses on embryonic development (for additional information on myelination, see Salzer 2015). We also discuss how the ability to change between differentiation states, a characteristic attribute of developing cells, is retained by mature Schwann cells, and explain how the ability of Schwann cells to change phenotype in response to injury allows the peripheral nervous system (PNS) to regenerate after damage.

\section{TWO TYPES OF EMBRYONIC NERVES}

Adult nerves are stable structures in which the nerve fibers are protected structurally by a collagen-rich, vascularized extracellular matrix (the endoneurium) linked to the basal lamina surrounding each axon-Schwann cell unit. The endoneurial environment is further protected by a surrounding multilayered cellular tube (the perineurium) that shields the nerve fibers from unwanted cells and molecules (Fig. 2).

A more dynamic and radically different structure, reminiscent of axon-glial organization in the central nervous system (CNS), is seen in early embryonic nerves (embryo day E14/15 in rat hind limb and E12/13 in mouse). These nerves consist of tightly packed axons and flattened, glial cell processes without significant extracellular space, matrix, or basal lamina. The glial cell bodies lie among the axons inside the nerve or at the nerve surface. These cells represent the first stage of the Schwann cell lineage, Schwann cell precursors (Figs. 3 and 4).

Editors: Ben A. Barres, Marc R. Freeman, and Beth Stevens

Additional Perspectives on Glia available at www.cshperspectives.org

Copyright (C) 2015 Cold Spring Harbor Laboratory Press; all rights reserved; doi: 10.1101/cshperspect.a020487

Cite this article as Cold Spring Harb Perspect Biol 2015;7:a020487 
K.R. Jessen et al.

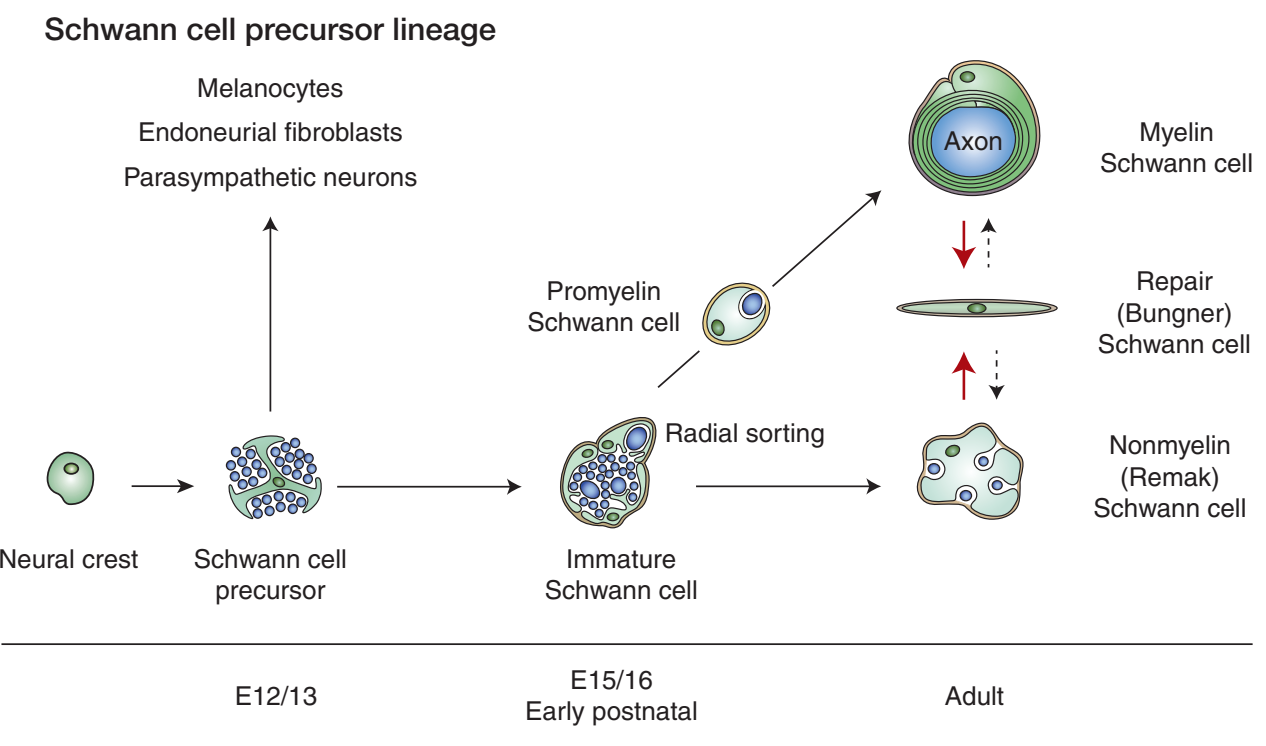

Figure 1. Main transitions in the Schwann cell precursor (SCP) lineage. The diagram shows both developmental and injury-induced transitions. Black uninterrupted arrows, normal development; red arrows, the Schwann cell injury response; stippled arrows, postrepair reformation of myelin and Remak cells. Embryonic dates (E) refer to mouse development. (Modified from Jessen and Mirsky 2012; reprinted, with permission and with contribution from Y. Poitelon and L. Feltri.)

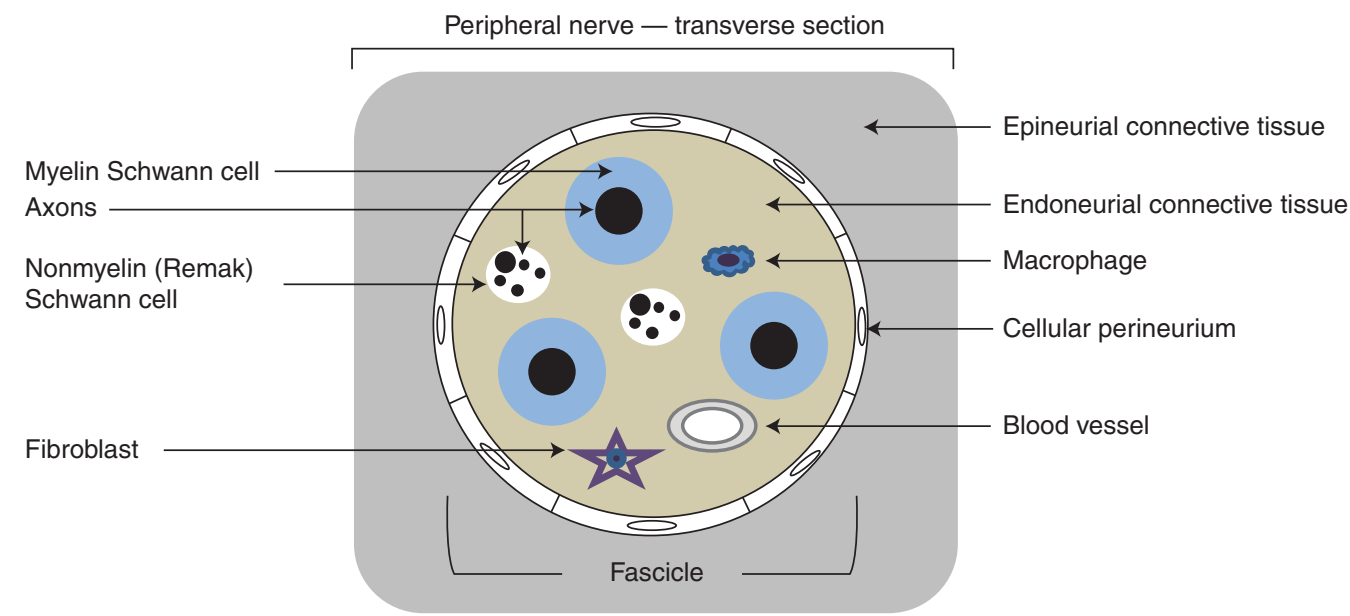

Figure 2. Diagram showing the architecture and main cellular components of an adult peripheral nerve. The main cellular structures within the nerve and the connective tissue compartments and the perineurium that protects them are indicated. This nerve contains one fascicle; larger nerves consist of several fascicles embedded in a common epineurium. The perineurium shown here, as a single cell layer, is most often multilayered. The drawing does not show the basal lamina that surrounds individual Schwann cell/axon units, blood vessels, and perineurial cells. 


\begin{tabular}{|c|c|c|c|c|}
\hline & & $\begin{array}{l}\text { Neural } \\
\text { crest }\end{array}$ & $\begin{array}{c}\text { Sch } \\
\text { precursors }\end{array}$ & $\begin{array}{l}\text { Immature } \\
\text { Sch }\end{array}$ \\
\hline 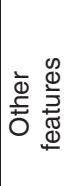 & & $\begin{array}{l}\text { ECM } \\
\text { associated }\end{array}$ & $\begin{array}{l}\text { Axon } \\
\text { associated }\end{array}$ & $\begin{array}{l}\text { Axon } \\
\text { associated } \\
\text { Basal lamina } \\
\text { Autocrine survival }\end{array}$ \\
\hline \multirow{3}{*}{ 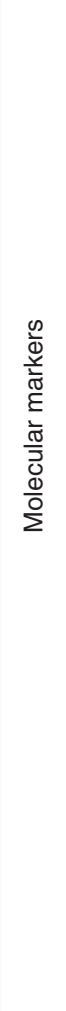 } & $\begin{array}{c}\text { No } \\
\text { change }\end{array}$ & $\begin{array}{l}\text { ErbB3 } \\
\text { L1 } \\
\text { p75NTR } \\
\text { Sox10 }\end{array}$ & $\begin{array}{l}\text { ErbB3 } \\
\text { L1 } \\
\text { p75NTR } \\
\text { Sox10 }\end{array}$ & $\begin{array}{l}\text { ErbB3 } \\
\text { L1 } \\
\text { p75NTR } \\
\text { Sox10 }\end{array}$ \\
\hline & $\begin{array}{l}\text { Up- } \\
\text { regulation }\end{array}$ & & $\begin{array}{l}\text { BFABP } \\
\text { Dhh } \\
\text { Po } \\
\text { GAP43 } \\
\text { PMP22 } \\
\text { PLP } \\
\text { Connexin } 29 \\
\text { PrPC } \\
\text { Astrotactin } \\
\text { Serpin2 } \\
\text { NFIB } \\
\text { Cad19 }\end{array}$ & $\begin{array}{l} \\
\text { GFAP } \\
\text { S100 } \\
\text { Oct6 } \\
\text { O4 } \\
\text { MAL } \\
\text { Galectin } \\
\text { Desmoyokin } \\
\text { Reelin } \\
\text { Decorin }\end{array}$ \\
\hline & $\begin{array}{l}\text { Down- } \\
\text { regulation }\end{array}$ & & & $\begin{array}{l}\alpha 4 \text { integrin } \\
\text { AP2 } \\
\text { Ncad } \\
\text { Cad19 }\end{array}$ \\
\hline
\end{tabular}

Figure 3. The phenotype of key stages in embryonic Schwann cell development. Each stage involves characteristic relationships with surrounding tissues and distinctive signaling properties (indicated in the panels immediately below the lineage drawing). Also shown are some of the molecular markers of the lineage. They fall into three groups: (1) markers that show no significant change between the three stages; (2) markers that are up-regulated during development (some of these are up-regulated at the crest to Schwann cell precursor transition; another group is up-regulated at the Schwann cell precursor to immature Schwann cell transition); (3) markers that are down-regulated at the Schwann cell precursor to immature Schwann cell transition. Sch, Schwann cell. (Modified from Jessen and Mirsky 2005; reprinted, with permission. See the original reference for detailed references to the molecules shown.) 
K.R. Jessen et al.

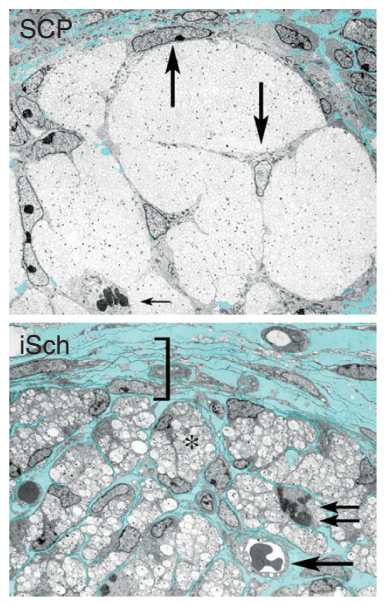

Figure 4. Schwann cell precursors (SCP) and immature Schwann cells (iSch) in embryonic nerves. (Upper panel) Transverse section of E14 rat sciatic nerve. Schwann cell precursors are embedded among the axons (downward large arrow) and at the surface of the nerve (upward large arrow). A dividing Schwann cell precursor is also seen (small arrow). Connective tissue (turquoise) is not found inside the nerve. (Lower panel) Transverse section of E18 rat sciatic nerve. One or a few immature Schwann cells together surround several axons, forming compact groups or families (asterisk). A dividing Schwann cell is seen (double arrows). Connective tissue (turquoise) containing blood vessels (large arrow) is present throughout the nerve surrounding the families. Bracket indicates the developing perineurium. (From Jessen and Mirsky 2005; adapted, with permission, from the authors.)

Around E16 in rat (E14 in mouse), this compact architecture changes rapidly. Extracellular spaces containing collagen appear within the nerve; blood vessels and fibroblasts are first seen, Schwann cell basal lamina starts to form, and the perineurial sheath can be discerned at the nerve surface. Concurrently, the phenotype of the glial cells in the nerve alters radically as Schwann cell precursors differentiate to immature Schwann cells (Figs. 3 and 4). By E18 in rat (E16 in mouse), nerves consist of axonSchwann cell bundles (families) embedded in extracellular matrix containing collagen and blood vessels. Nascent Schwann cell basal lamina appears and early perineurium surrounds the nerve (Jessen and Mirsky 2005).
The period around E16 in rat (E14 mouse) is, therefore, a turning point when generation of Schwann cells from precursors coincides with the establishment of a tissue architecture similar to that of adult nerves.

\section{SCHWANN CELL PRECURSORS}

\section{Developmental Potential}

Schwann cell precursors are the glial cells of early embryonic nerves. They are generated from the neural crest and, in turn, generate immature Schwann cells. They are also the source of endoneurial fibroblasts and, therefore, the connective tissue that appears in late embryonic nerves (Joseph et al. 2004; Jessen and Mirsky 2005). This is consistent with the observation that Schwann cell precursors disappear from developing nerves at the same time as immature Schwann cells and fibroblasts appear (Wanner et al. 2006a).

Schwann cell precursors also generate melanoblasts that migrate from nerves to skin. The generation of melanocytes requires down-regulation of the transcription factor FoxD3, and cross-regulatory interactions between the transcription factors Sox 2 and Mitf (Kaucká and Adameyko 2013; Nitzan et al. 2013).

Furthermore, experiments from two laboratories show that, in vivo, parasympathetic neurons are derived from Schwann cell precursors in embryonic peripheral nerves (Dyachuk et al. 2014; Espinosa-Medina et al. 2014). Because these cells also give rise to melanocytes and endoneurial fibroblasts, Schwann cell precursors have a choice of at least four potential fates. The broad developmental potential of these early PNS glial cells is reminiscent of early CNS glia, radial glial cells that give rise to neurons, astrocytes, oligodendrocytes, and ependymal cells (Merkle et al. 2004).

\section{Phenotype}

Schwann cell precursors show multiple phenotypic differences from both neural crest cells and immature Schwann cells as shown by molecular and gene array analysis (see Fig. 3 for examples 
of phenotypic changes) (Buchstaller et al. 2004; D'Antonio et al. 2006b). They differ from crest cells because they express glial differentiation genes and other factors not expressed by crest cells, because they are found in association with axons in nerves, a characteristic glial feature, rather than migrating through extracellular matrix, and because they respond differently to survival, proliferation, and differentiation signals (Jessen and Mirsky 2005, 2012; Woodhoo and Sommer 2008). Schwann cell precursors and immature Schwann cells differ substantially in molecular expression, including up-regulation of S100 in immature Schwann cells (Fig. 3). Perhaps the most striking difference concerns survival regulation, because Schwann cell precursors are acutely dependent on the axon-associated survival signal neuregulin 1 type III, whereas immature Schwann cells survive in culture without addition of survival factors because of secretion of autocrine survival signals (Dong et al. 1999; Meier et al. 1999).

\section{THE GENERATION OF SCHWANN CELL PRECURSORS FROM THE NEURAL CREST}

Signals that control the emergence of the glial lineage from the trunk crest in rodents are still poorly known, and unlike other crest-derived lineages, transcription factors that specify glial differentiation from the crest have not been described.

The transcription factor FoxD3 is expressed in early migrating crest. It inhibits the development of neurons and melanocytes and is down-regulated in these lineages as they emerge. FoxD3 is, however, compatible with glial differentiation and is expressed at early stages of the Schwann cell lineage (Nitzan et al. 2013). The transcription factor Sox10 is required for the generation of Schwann cell precursors. Like FoxD3, it is generally expressed by early crest cells and, therefore, does not specify glia. Sox10 is suppressed in neurons and inhibits neurogenesis, but is expressed in early melanocytes. In crest cells, Sox10 maintains expression of ErbB3 receptors for neuregulin, a growth factor that indirectly promotes gliogenesis from crest cells (Britsch et al. 2001).
Neuregulin 1 interacts with ErbB2/ErbB3 receptors on Schwann cell lineage cells and is broadly implicated in Schwann cell development (Birchmeier and Nave 2008). It suppresses neurogenesis, which could indirectly increase gliogenesis. However, the following argues that neuregulin 1 is not required for the generation of glia from crest cells: Schwann cells are formed despite inactivating mutations in ErbB3 receptors in zebrafish (Lyons et al. 2005); in vitro Schwann cell precursors and immature Schwann cells appear readily from crest without addition of neuregulin 1 (Shah et al. 1994); a major category of PNS glia closely related to Schwann cells, namely, satellite cells in dorsal root sensory ganglia (DRG), appear normally in mouse mutants in which neuregulin 1 signaling is inactivated (Garratt et al. 2000).

Nevertheless, in vitro exposure of crest cells or other early cells with PNS gliogenic potential to neuregulin 1 increases Schwann cell numbers (Shah et al. 1994). This is probably caused by suppression of other differentiation options or the action of neuregulin 1 at later lineage stages, because neuregulin 1 promotes the generation of immature Schwann cells from Schwann cell precursors and stimulates Schwann cell division (see below).

Notch signaling also increases the number of Schwann cells in crest cultures (Kubu et al. 2002). This likely results from the fact that Notch promotes Schwann cell generation from precursors, and Schwann cell proliferation (see below) (Woodhoo et al. 2009), rather than the involvement of Notch in direct gliogenesis from the neural crest (discussed in Jessen and Mirsky 2005).

\section{THE SURVIVAL AND DIFFERENTIATION OF SCHWANN CELL PRECURSORS}

Schwann cell precursors, unlike Schwann cells, die when removed from axons in vitro. Coculture with neurons prevents this, and the neuron-associated survival signal has been identified as neuregulin (Dong et al. 1995). In the chick embryo, Schwann cell precursors also die when axons degenerate, and this is prevented by neuregulin. Furthermore, Schwann cell precur- 
K.R. Jessen et al.

sors are reduced or absent from nerves of mice in which neuregulin signaling has been inactivated (Birchmeier 2009). Neuregulin is expressed on axons and in embryonic DRG and motor neurons. Together, this indicates that the survival of Schwann cell precursors and, by implication, the generation of Schwann cells and myelination, is crucially dependent on axonal neuregulin 1.

Although neuregulin 1 exists in many isoforms, most of its effects in the Schwann cell lineage are mediated by neuregulin 1 type III (Birchmeier 2009). In postnatal nerves, neuregulin 1 signaling between axons and Schwann cells is modulated by proteases including Bace 1 $(\beta$-secretase) and TACE (ADAM17) (Hu et al. 2006; La Marca et al. 2011; Fleck et al. 2012). The role of these proteins in embryonic nerves has not been investigated.

Like neuregulin 1, Notch ligands are expressed on embryonic axons and the Notch ligand Jagged 1 is also present on Schwann cell precursors. In mice with genetic inactivation of Notch 1 or the transcription factor RBPJ, which is essential for classical Notch signaling, Schwann cell generation from precursors is delayed, whereas, conversely, Schwann cells appear more rapidly in mice in which Notch signaling is enhanced (Woodhoo et al. 2009). Thus, the role of Notch signaling in Schwann cell precursors is to promote their conversion to Schwann cells. The underlying mechanism is likely to involve neuregulin 1. Notch elevates the levels of ErbB3 neuregulin receptors in the precursors, which increases the effectiveness of neuregulin 1 signaling to these cells (Woodhoo et al. 2009). This, together with the fact that neuregulin 1 directly accelerates Schwann cell precursor differentiation (Brennan et al. 2000), allows Schwann cell generation to be indirectly promoted by Notch.

The generation of Schwann cells is also subject to negative regulation. One of the signals involved is endothelin. Endothelin delays the appearance of immature Schwann cells from Schwann cell precursors in vitro, and inactivation of endothelin B receptors in vivo results in premature appearance of these cells, confirming that the function of endothelin is to retard Schwann cell generation (Brennan et al. 2000).
Enforced expression of the transcription factor AP2 $\alpha$ in Schwann cell precursors also slows the conversion of precursors to Schwann cells, whereas, in vivo, AP2 $\alpha$ is expressed in the precursors but sharply down-regulated in immature Schwann cells. This suggests that AP2 $\alpha$ is involved in maintaining the Schwann cell precursor phenotype (Stewart et al. 2001).

\section{THE FUNCTION OF SCHWANN CELL PRECURSORS}

In addition to giving rise to immature Schwann cells, endoneurial fibroblasts, and parasympathetic neurons, Schwann cell precursors control nerve fasciculation and are implicated in the survival of developing DRG and motoneurons.

\section{Nerve Fasciculation}

Surprisingly, axons can group to form a nerve and are able to navigate correctly for considerable distances in the embryo without the help of glial cells. This can be seen in mice with genetic inactivation of neuregulin signaling, in which nerves follow a normal position and trajectory from the spinal cord toward their targets, although they lack Schwann cell precursors and are essentially composed only of axons (Meyer and Birchmeier 1995; Morris et al. 1999; Woldeyesus et al. 1999). In agreement, motor nerves grow correctly toward their targets in Splotch (Pax3) mouse mutants, although both Schwann cell precursors and DRG sensory axons are missing (Grim et al. 1992). Comparable observations have been made in other models (Keynes 1987), including zebrafish, in which initial outgrowth and guidance of axons in the lateral line is normal without glia (Raphael and Talbot 2011).

Although nerves without Schwann cell precursors or early Schwann cells broadly run their normal course in the embryo, the axons in these nerves are defasciculated distally with abnormal branching and terminal sprouting within their target fields, leading to inaccurate location of synaptic sites (Birchmeier 2009). This is unsurprising in view of the cellular architecture of growing nerve endings. Schwann cell precursors 
are abundant at these endings, forming complex scaffolds around growth cones. Although the resulting structure appears irregular, quantitatively the amount of membrane contact between precursors and growth cones is remarkably constant from nerve to nerve (Wanner et al. 2006b). Clearly, this intricate arrangement between neurons and glia is essential for normal nerve branching and interactions with targets.

\section{The Survival of DRG and Motoneurons}

In neuregulin 1, ErbB2, ErbB3, or Sox10 mutant mouse embryos without Schwann cell precursors (see above), both DRG sensory neurons and spinal cord motoneurons develop normally and are initially present in normal numbers. But later, large-scale death of both populations occurs at cervical and lumbar levels. This is seen at E12 in ErbB2 mutant mice (Woldeyesus et al. 1999), but later in ErbB3 and Sox10 mutants. The simplest explanation of this striking neuronal death, particularly in which it is seen early, is that Schwann cell precursors provide essential neurotrophic support.

In mutants in which neuronal death occurs later, when significant neuron-target interactions have started (e.g., Wolpowitz et al. 2000), defective relationships with the target and inability to access target-derived growth factors probably contribute to neuronal loss.

\section{IMMATURE SCHWANN CELLS IN EMBRYONIC NERVES}

In late embryonic nerves (from E15/16 in mouse and E17/18 in rat), Schwann cell precursors have converted to immature Schwann cells (Fig. 4). They envelop groups of axons communally, forming irregular axon/Schwann cell columns (families), each of which is covered by a nascent basal lamina and surrounded by extracellular matrix that has now formed within the nerve (Webster et al. 1973). There is little evidence for the persistence of Schwann cell precursors significantly after this time. During the next few days (E19/20 in mouse and E21 in rat), Schwann cell proliferation and death match axon and Schwann cell numbers. Radial sorting also starts at this time, involving single axons segregating from the axon/Schwann cell families to become individually ensheathed by a Schwann cell. This is a precondition for myelination, which subsequently takes place in the case of larger axons.

\section{What Drives Schwann Cell Proliferation?}

DNA synthesis occurs in Schwann cell precursors and immature Schwann cells throughout embryogenesis. The precursor to immature Schwann cell conversion is accompanied by strongly increased proliferation, which is likely to be related to a graded increase in intracellular cAMP controlled by levels of GPR126 (ArthurFarraj et al. 2011; Mogha et al. 2013), although proliferation falls postnatally during myelination (Stewart et al. 1993; Yu et al. 2005; Chernousov et al. 2008). Proliferation is seldom seen in cells that have segregated to ensheath individual axons and myelinating cells do not divide (Webster et al. 1973). Schwann cell proliferation in vivo is driven by axon-associated signals, such as Notch and neuregulin 1, soluble signals, such as transforming growth factor (TGF)- $\beta$, and signals derived from the basal lamina, such as laminin.

Notch receptor is present on Schwann cells and Notch ligands are present on axons. Schwann cell-specific Notch inactivation results in a substantial reduction in DNA synthesis and Schwann cell numbers in neonatal nerves (Woodhoo et al. 2009). Notch activation is a potent inducer of Schwann cell division in vitro. This shows that Notch signaling from axons to Schwann cells drives Schwann cell proliferation in developing nerves (Woodhoo et al. 2009).

Neuregulin 1 is also present on axons; ErbB2 and ErbB3 receptors are on Schwann cells and neuregulin 1 stimulates Schwann cell proliferation in vitro (Levi et al. 1995). In zebrafish, ErbB2 receptor blockers reduce Schwann cell division (Lyons et al. 2005). Studies of mouse mutants with genetic inactivation in neuregulin 1 signaling to test whether neuregulin 1 drives the proliferation of developing Schwann cells are not available (for discussion, see Jessen and Mirsky 2012). In adult mice, injury-induced Schwann cell proliferation appears to 
K.R. Jessen et al.

be neuregulin 1 independent (Atanasoski et al. 2006; Fricker et al. 2013).

TGF- $\beta$ stimulates Schwann cell proliferation in culture, although, under some conditions, it induces apoptosis (Ridley et al. 1989; Einheber et al 1995; Parkinson et al 2001). In type II TGF- $\beta$ receptor mutant mice, there is a substantial reduction of Schwann cell DNA synthesis, showing that TGF- $\beta$ drives Schwann cell division in perinatal nerves (D'Antonio et al. 2006a). Decreased proliferation is, however, not reflected in decreased cell numbers, likely because of the dual capacity of TGF- $\beta$ to promote proliferation or death depending on context, as indicated by the observation that Schwann cell death is also reduced in these TGF- $\beta$ receptor mutants. The function of TGF- $\beta$ may be to amplify the proliferation of cells with tight axonal contact, but to kill supernumerary cells with less effective axonal affiliation (D'Antonio et al. 2006a).

As the major component of the basal lamina, laminin contacts Schwann cells to which it binds via receptors that include dystroglycan and $\beta 1$ integrin. Laminin promotes Schwann cell proliferation in vivo, and lack of the downstream effector of $\beta 1$ integrin, cdc42, reduces proliferation in immature Schwann cells (Yu et al. 2005; Chernousov et al. 2008; Feltri et al. 2008).

\section{Control of Schwann Cell Survival}

Survival regulation changes radically at the precursor-to-Schwann cell conversion. Precursor survival depends on axon-associated (neuregulin 1) signals (Dong et al. 1995), whereas immature Schwann cells, even in embryonic nerves, bypass this strict axon dependence with the help of autocrine survival circuits including IGF-2, NT3, PDGF-B, leukemia inhibitory factor (LIF), and lysophosphatidic acid (Jessen and Mirsky 2005). Such circuits are absent from precursors. Schwann cell survival is, therefore, density dependent in vitro, and the Schwann cell population survives the loss of axonal contact in damaged nerves. Nevertheless, injury increases Schwann cell apoptosis particularly in neonatal nerves but also, to a lesser degree, in the adult (Grinspan et al. 1996; Ferri and Bisby 1999; Syroid et al. 2000), indicating a persistent but gradually diminishing contribution of axonal signals to Schwann cell survival in the medium term. After longer periods, however, most Schwann cells without axonal contact in injured adult nerves die (Hoke 2006; Sulaiman and Gordon 2009). The emergence of axon-independent survival mechanisms before birth and their persistence in adults makes biological sense because nerve regeneration depends on the presence of living Schwann cells in the nerve stump distal to the injury (see below).

At least two signals, TGF- $\beta$ signaling through type TGF- $\beta$ II receptor and nerve growth factor (NGF) acting through $\mathrm{p} 75^{\mathrm{NTR}}$, potentially kill Schwann cells (Syroid et al. 2000; D'Antonio et al. 2006a). Of these, only TGF- $\beta$ promotes Schwann cell death during normal development (see above). TGF- $\beta$ and NGF contribute to increased Schwann cell death after injury in neonatal nerves. It is not known whether they contribute to injury-induced Schwann cell death in adults or whether they play a part in the death of long-term denervated Schwann cells.

\section{THE REACTION OF SCHWANN CELLS TO NERVE DAMAGE}

There are two main types of severe peripheral nerve injury (Burnett and Zager 2004). One is axonotmesis, in which axons are disrupted but the connective tissue sheaths and the Schwann cell containing basal lamina tubes remain intact. When this is modeled in rodents by nerve crush, axonal regeneration is remarkably effective and function is restored in 3-4 wk.

The other injury is neurotmesis, in which axons, connective sheaths, and basal lamina tubes are interrupted. When studied in rodents by nerve cut without repair, a tissue bridge forms between the two ends of the nerve, through which axons closely accompanied by Schwann cells (regeneration units) grow to reach the distal stump (Morris et al. 1972; Meller 1987; Parrinello et al. 2010). Alternatively, after cut the proximal and distal stumps can be reat- 
tached, leaving only a microscopic gap to be bridged by regeneration units. This repair mimics the standard clinical treatment of many injuries, although in severe injuries a nerve autograft or nerve conduit is required with variable success (Battiston et al. 2005). With or without repair, functional recovery after nerve cut is generally poor, especially in man but frequently in rodents. An important reason for this is the targeting errors made by regenerating axons in the critical interphase between the proximal and distal nerve stumps, leading to incorrect target innervation (Witzel et al. 2005; Hoke 2006).

Distal to the injury, the consequences are similar irrespective of whether axons are interrupted by crush or cut. The axons of the distal nerve die, triggering a series of events involving Schwann cells, macrophages, and other bloodborne cells. This complex and constructive process (Wallerian degeneration) builds an environment tailored to support the survival of injured neurons, axon regrowth, and guidance (Chen et al. 2007; Vargas and Barres 2007; Allodi et al. 2012) (for details, see the section The Schwann Cell Injury Response in the Distal Stump). The process depends critically on the unusual plasticity of myelin and Remak cells and their ability to adopt new identities during the repair process.

\section{SCHWANN CELL PLASTICITY}

Although the discussion below will be framed in terms of myelin cells, similar principles are likely to apply to Remak cells. The differentiation state of the myelin Schwann cell is not fixed, unlike that of its relative the oligodendrocyte, and the cell can readily be destabilized (Jessen and Mirsky 2008). On the one hand, this renders the cells vulnerable to immune assaults or genetic abnormalities seen in demyelinating neuropathies and in tumors in which Schwann cells exist in varying, poorly characterized demyelinated states and/or proliferate abnormally (Scherer and Wrabetz 2008; Lehmann et al. 2012; Ribeiro et al. 2013). On the other hand, the plasticity of myelin cells allows them to respond adaptively to injury by converting to cells that support regeneration. Such cells are seen in the distal stump of cut or crushed nerves. Here, Schwann cells are left without axonal contact, often for a long time, until regenerating axons reach them as they grow through the distal nerve stump toward their targets. (Sulaiman and Gordon 2009; Arthur-Farraj et al. 2012). Other Schwann cells accompany growing axon tips to form the regeneration units found in the bridge or interphase between proximal and distal stumps of cut nerves (Morris et al. 1972; Friede and Bischhausen 1980; Meller 1987; Parrinello et al. 2010). Although these cells are not likely to have lost contact with axons, they have abandoned myelin differentiation, and represent the daughter cells of Schwann cells associated with cut axons just proximal to the injury. An additional Schwann cell group is represented by cells that migrate into the nerve bridge from the distal stump.

Because Schwann cells function in more than one mode during regeneration, it is likely that distinct populations of repair-supportive cells exist, showing characteristic phenotypes or differentiation states depending on location, timing, and type of injury. A nice example of this is when Schwann cells come into direct contact with fibroblasts, specifically, at the injury site following a transection, and this contact triggers migratory behavior important for guiding regrowing axons across the wound site ( $\mathrm{Pa}$ rrinello et al. 2010).

The injury-induced change in Schwann cell differentiation during Wallerian degeneration has been characterized as dedifferentiation (e.g., Chen et al. 2007; discussed in Jessen and Mirsky 2008), but it is also commonly described as activation (Armstrong et al. 2007; Campana 2007; Webber and Zochodne 2010; Allodi et al. 2012). This implies, somewhat confusingly, that this process involves either the loss or the gain, respectively, of cellular phenotypes. In fact, the conversion of myelin cells to repair Schwann cells involves both a loss (dedifferentiation) and a gain (activation) of phenotypes as described in the following section. This combination is known from a number of other systems and constitutes one of the hallmarks of cell type conversions referred to as transdifferentiation 
K.R. Jessen et al.

or cellular reprogramming (Arthur-Farraj et al. 2012).

\section{THE SCHWANN CELL INJURY RESPONSE IN THE DISTAL STUMP}

Although the degeneration of axons in the distal stump takes 2-4 d, Schwann cell responses to axonal interruption can be detected earlier, some within hours of injury, suggesting that injured axons alert Schwann cells to axon death through an as-yet unknown mechanism (Martini et al. 2008; Rotschenker 2011). The Schwann cell response rapidly develops into a radical phenotypic change. This process has two major components.

One of these is the reversal of myelin differentiation. Molecules that characterize Schwann cells before myelination (the immature Schwann cell stage) are up-regulated, comprising L1, NCAM, p75NTR, and glial fibrillary acidic protein (GFAP), whereas myelinassociated genes are down-regulated. These include the key myelin transcription factor Egr2 (Krox20), enzymes of cholesterol synthesis, structural proteins, such as $\mathrm{P} 0$, myelin basic protein (MBP), and membrane-associated proteins like myelin-associated glycoprotein (MAG) and periaxin (Jessen and Mirsky 2008).

The other component of the Schwann cell injury response is the appearance of novel phenotypes associated with neither Schwann cells in normal undisturbed nerves nor with immature Schwann cells. These features have in common that they contribute critically to the repair process. This includes, first, the up-regulation of a group of neurotrophic factors that promote the survival of injured neurons and axonal elongation. Among these proteins are GDNF, artemin, BDNF, NT3, NGF, VEGF, and pleiotrophin (Fontana et al. 2012; Brushart et al. 2013). Second, the Schwann cells in the distal stump upregulate the expression of cytokines including tumor necrosis factor (TNF)- $\alpha$, LIF, interleukin (IL)-1 $\alpha$, IL-1 $\beta$, LIF, and MCP-1, which recruit macrophages; and, third, Schwann cells activate a cell-intrinsic myelin breakdown process, likely to be autophagy (L Carty, R Mirsky, and KR
Jessen, unpubl.), which is thought to be responsible for the bulk of myelin breakdown during the first 5-7 d after injury (Hirata and Kawabuchi 2002; Rotschenker 2011; Vidal et al. 2013). These events are likely to promote repair in a number of ways. In addition to attracting macrophages, cytokines, such as IL-6 and LIF, can act directly on neurons to promote axonal regeneration, whereas invading macrophages provide an additional and sustained source of cytokines. They also promote vascularization of the distal nerve (Barrette et al. 2008), in addition to cooperating with Schwann cells in clearing myelin, which potentially inhibits axon growth (Hirata and Kawabuchi 2002). The fourth component of the Schwann cell injury response is the formation of regeneration tracks. The myelin cells that previously formed flattened sheaths around axons, adopt an elongated bipolar morphology, allowing them to align to form a Schwann cell column named Bungner band inside each of the basal lamina tubes that formerly enclosed a myelin Schwann cell and its axon. These columns form tracks from the injury site to the nerve target areas, with the (Bungner) Schwann cells providing essential substrate and guidance cues for regenerating axons (Fig. 5).

The combined activation of this set of proregenerative features, or repair program, and down-regulation of the myelin program results in a novel Schwann cell phenotype that is adapted to support nerve repair, the repair Schwann cell. This repair (Bungner) cell is unambiguously distinct, both from the immature Schwann cell in developing nerves before myelination and from Schwann cell precursors in earlier embryonic nerves. The conversion of myelin cells to repair cells is controlled by the transcription factor c-Jun that is activated in Schwann cells of injured nerves through mechanisms that are still unknown (Arthur-Farraj et al. 2012).

Although Schwann cells reenter the cell cycle after injury, and their number in the distal stump increases severalfold, regeneration following a crush injury is equally effective in mice in which Schwann cell proliferation is inhibited (Kim et al. 2000; Atanasoski et al. 2001; 


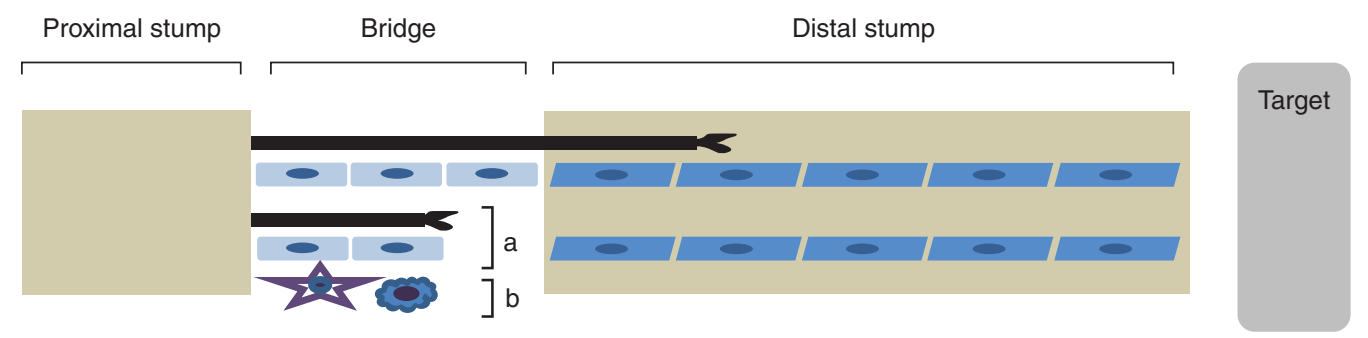

Figure 5. Key tissue components of regenerating nerves. (a) Regeneration unit, and (b) fibroblasts and immune cells providing essential signals to the Schwann cells of the regeneration units. In the distal stump, denervated Schwann cells convert to a repair supportive phenotype. These repair (Bungner) Schwann cells form regeneration tracks (Bungner bands; dark blue cells) that guide regenerating axons back to their targets and provide essential trophic support for injured neurons. After crush injury, axons are severed but the Schwann cell basal lamina tubes and connective sheaths remain continuous between the proximal and distal stump. This allows axons to reach the distal stump within their original basal lamina tubes. After nerve cut, the length of the bridge depends on the extent of the injury and the nature of any subsequent surgical intervention.

Yang et al. 2008). This suggests that the conversion of myelin Schwann cells to repair Schwann cells does not depend on reentry to the cell cycle.

\section{CONTROL AND MAINTENANCE OF THE REPAIR PHENOTYPE}

Remarkably, individual activation of certain signaling pathways in myelin cells is sufficient to destabilize the cells and cause demyelination. The existence of such trigger points is in line with the flexibility of the myelin phenotype and is likely to contribute to the vulnerability of these cells to cell-extrinsic changes. These pathways include Raf/ERK signaling and the transcriptional regulators Notch and c-Jun. Other transcription factors, like Notch and cJun, are characterized as negative regulators of myelination, including Sox2, Pax3, and Id4, are implicated in a similar function (Jessen and Mirsky 2008), as are the JNK and p38 MAP kinase pathways (Kioussi et al. 1995; Le et al. 2005; Mager et al. 2008; Doddrell et al. 2012; Hossain et al. 2012; Yang et al. 2012; DK Wilton, R Mirsky, and KR Jessen, unpubl.).

The Raf/ERK pathway appears to play a central role in mediating the repair phenotype in Schwann cells. Activation of this pathway in adult myelinating Schwann cells, to levels ob- served following an injury, is sufficient to trigger multiple aspects of the repair response in the absence of injury or axonal breakdown (Harrisingh et al. 2004; Napoli et al. 2012). This includes Schwann cell-autonomous effects, such as demyelination and proliferation, but also non-cell-autonomous effects, such as activation of the pathway, is sufficient to cause both a breakdown in the blood-nerve barrier and as robust an inflammatory response as seen following an injury. Importantly, the response is reversible-following the switch-off of the ERK signal, the Schwann cells remyelinate and the inflammatory response resolves. The control of the multicellular response by the Schwann cell provides a mechanism of organizing the repair far from the site of the original injury and allows for a coordinated resolution of this response as the nerve repairs. Interestingly, ERK-activation is associated with both neuropathies and Schwann cell-derived tumors, in which inflammatory responses play key roles indicating that dysregulation of this pathway can contribute to pathologies by mimicking the repair response.

c-Jun is rapidly up-regulated in Schwann cells distal to nerve injury. This protein has a central role in the transformation of myelin Schwann cells to Bungner repair cells because c-Jun controls both components of the Schwann cell injury response in the distal stump. It promotes the down-regulation of the myelin pro- 
K.R. Jessen et al.

gram (Parkinson et al. 2008), and, importantly, c-Jun is also required for the normal activation of the repair program. Thus, $c$-Jun ${ }^{-/}$Schwann cells in injured distal stumps fail to normally up-regulate expression of key trophic factors and cell surface proteins that support neuronal growth, including GDNF, artemin and BDNF, p75NTR, and N-cadherin. They form abnormal regeneration tracks and show long-term delay in myelin breakdown. For these reasons, the generation of functional repair Schwann cells fails in $\mathrm{c}-\mathrm{Jun}^{-/}$mouse mutants, resulting in striking failure of regeneration and functional recovery (Arthur-Farraj et al. 2012).

Recently, reduced activation of Schwann cell c-Jun in injured nerves has been implicated in the reduced regenerative capacity of peripheral nerves that characterizes older animals (Painter et al 2014). This important suggestion awaits direct experimental confirmation.

Notch signaling is also activated in distal stump Schwann cells, where it is likely to have a number of functions (Woodhoo et al. 2009). Best characterized of these is the promotion of the myelin dedifferentiation component of the injury response. Even in uninjured adult nerves, activation of Notch is sufficient to trigger demyelination (Woodhoo et al. 2009).

Following a nerve transection, regrowing axons need to find their way across the bridge formed between the nerve stumps. The bridge is composed of a mixture of inflammatory cells and matrix, an apparently hostile environment and likely to lack the guidance cues present during development. In this situation, Schwann cells have a further repair role, in that they emerge as cords of cells from each stump to bridge the gap and carry the regrowing axons from the proximal stump along with them. Interestingly, this migratory behavior is dependent on genes switched on as the Schwann cells dedifferentiate, EphB2, Sox2, and N-cadherin. However, a cell type only found in large numbers at the wound site (the bridge) activates this pathway in these "primed" Schwann cells. Thus, ephrin B expressed by fibroblasts activates EphB2 on the Schwann cells that, via Sox2, triggers the relocalization of $\mathrm{N}$-cadherin to Schwann cell junctions. This causes a switch from normally repulsive behavior to attractive behavior that is essential for the formation of the migratory cords that cross the bridge (Parrinello et al. 2010).

The notion that an activation of a repair program is superimposed on the dedifferentiated, immature Schwann cell-like state to generate a cell equipped to promote repair, prompts the question not only of how this cell is generated, outlined above, but also how the repair phenotype is maintained. This is particularly relevant in larger animals in which distal stump Schwann cells may be without axonal contact for many months because of the slow rate of axonal growth. It is well established that, during this time, the distal nerve stump gradually loses its repair-supportive capacity, and that this decline is one of the key reasons for frequent regeneration failure in humans (Hoke 2006; Sulaiman and Gordon 2009). This suggests that the repair Schwann cell phenotype is labile and indicates that maintenance of the repair phenotype is a critical clinical issue. Study of the signaling pathways that maintain the Bungner repair phenotype is, therefore, an important future research direction in this area.

\section{ACKNOWLEDGMENTS}

Work from the laboratory of K.R.J. and R.M. included in this article is supported by Wellcome Trust Program and project grants and a Medical Research Council (MRC) project grant. K.R.J. and R.M. also received funding from the European Community's Seventh Framework Program (FP7/2007-2013) under Grant agreement No. HEALTH-F2-2008-201535. Work from the laboratory of A.C.L. is funded by Cancer Research UK (CRUK) and the American Institute for Cancer Research (AICR).

\section{REFERENCES}

${ }^{*}$ Reference is also in this collection.

Allodi I, Udina E, Navarro X. 2012. Specificity of peripheral nerve regeneration: Interactions at the axon level. Prog Neurobiol 98: 16-37.

Armstrong SJ, Wiberg M, Terenghi G, Kingham PJ. 2007. ECM molecules mediate both Schwann cell proliferation 
and activation to enhance neurite outgrowth. Tissue Eng 13: $2863-2870$.

Arthur-Farraj P, Wanek K, Hantke J, Davis CM, Jayakar A, Parkinson DB, Mirsky R, Jessen KR. 2011. Mouse Schwann cells need both NRG1 and cyclic AMP to myelinate. Glia 59: 720-733.

Arthur-Farraj PJ, Latouche M, Wilton DK, Quintes S, Chabrol E, Banerjee A, Woodhoo A, Jenkins B, Rahman M, Turmaine M, et al. 2012. c-Jun reprograms Schwann cells of injured nerves to generate a repair cell essential for regeneration. Neuron 75: 633-647.

Atanasoski S, Shumas S, Dickson C, Scherer SS, Suter U. 2001. Differential cyclin D1 requirements of proliferating Schwann cells during development and after injury. Mol Cell Neurosci 18: 581-592.

Atanasoski S, Boentert M, De Ventura L, Pohl H, Baranek C, Beier K, Young P, Barbacid M, Suter U. 2006. Postnatal Schwann cell proliferation but not myelination is strictly and uniquely dependent on cyclin-dependent kinase 4 (cdk4). Mol Cell Neurosci 37: 519-527.

Barrette B, Hébert MA, Filali M, Lafortune K, Vallières N, Gowing G, Julien JP, Lacroix S. 2008. Requirement of myeloid cells for axon regeneration. J Neurosci 28: 9363-9376.

Battiston B, Geuna S, Ferrero M, Tos P. 2005. Nerve repair by means of tubulization: Literature review and personal clinical experience comparing biological and synthetic conduits for sensory nerve repair. Microsurgery 25: 258-267.

Birchmeier C. 2009. ErbB receptors and the development of the nervous system. Exp Cell Res 315: 611-618.

Birchmeier C, Nave KA. 2008. Neuregulin-1, a key axonal signal that drives Schwann cell growth and differentiation. Glia 56: 1491-1497.

Brennan A, Dean CH, Zhang AL, Cass DT, Mirsky R, Jessen KR. 2000. Endothelins control the timing of Schwann cell generation in vitro and in vivo. Dev Biol 227: 545-557.

Britsch S, Goerich DE, Riethmacher D, Peirano RI, Rossner M, Nave KA, Birchmeier C, Wegner M. 2001. The transcription factor Sox 10 is a key regulator of peripheral glial development. Genes Dev 15: 66-78.

Brushart TM, Aspalter M, Griffin JW, Redett R, Hameed H, Zhou C, Wright M, Vyas A, Höke A. 2013. Schwann cell phenotype is regulated by axon modality and centralperipheral location, and persists in vitro. Exp Neurol 247: 272-281.

Buchstaller J, Sommer L, Bodmer M, Hoffmann R, Suter U, Mantei N. 2004. Efficient isolation and gene expression profiling of small numbers of neural crest stem cells and developing Schwann cells. J Neurosci 24: 2357-2365.

Burnett MG, Zager EL. 2004 Pathophysiology of peripheral nerve injury: A brief review. Neurosurg Focus 16: pE1.

Campana WM. 2007. Schwann cells: Activated peripheral glia and their role in neuropathic pain. Brain Behav Immun 21: 522-527.

Chen ZL, Yu WM, Strickland S. 2007. Peripheral regeneration. Annu Rev Neurosci 30: 209-233.

Chernousov MA, Yu WM, Chen ZL, Carey DJ, Strickland S. 2008. Regulation of Schwann cell function by the extracellular matrix. Glia 56: 1498-1507.
D’Antonio M, Droggiti A, Feltri ML, Roes J, Wrabetz L, Mirsky R, Jessen KR. 2006a. TGF- $\beta$ type II receptor signaling controls Schwann cell death and proliferation in developing nerves. J Neurosci 26: 8417-8427.

D’Antonio M, Michalovich D, Paterson M, Droggiti A, Woodhoo A, Mirsky R, Jessen KR. 2006b. Gene profiling and bioinformatics analysis of Schwann cell embryonic development and myelination. Glia 53: 501-515.

Doddrell RD, Dun XP, Moate RM, Jessen KR, Mirsky R, Parkinson DB. 2012. Regulation of Schwann cell differentiation and proliferation by the Pax-3 transcription factor. Glia 60: 1269-1278.

Dong Z, Brennan A, Liu N, Yarden Y, Lefkowitz G, Mirsky R, Jessen KR. 1995. Neu differentiation factor is a neuronglia signal and regulates survival, proliferation, and maturation of rat Schwann cell precursors. Neuron 15: $585-$ 596.

Dong Z, Sinanan A, Parkinson D, Parmantier E, Mirsky R, Jessen KR. 1999. Schwann cell development in embryonic mouse nerves. J Neurosci Res 56: 334-348.

Dyachuk V, Furlan A, Shahidi MK, Giovenco M, Kaukua N, Konstantinidou C, Pachnis V, Memic F, Marklund U, Müller T, et al. 2014. Parasympathetic neurons originate from nerve-associated peripheral glial progenitors. Science 345: 82-87.

Einheber S, Hannocks MJ, Metz CN, Rifkin DB, Salzer JL. 1995. Transforming growth factor- $\beta 1$ regulates axon/ Schwann cell interactions. J Cell Biol 129: 443-458.

Espinosa-Medina I, Outin E, Picard CA, Chettouh Z, Dymecki S, Consalez GG, Coppola E, Brunet JF. 2014. Parasympathetic ganglia derive from Schwann cell precursors. Science 345: 87-90.

Feltri ML, Suter U, Relvas JB. 2008. The function of RhoGTPases in axon ensheathment and myelination. Glia 56: $1508-1517$.

Ferri CC, Bisby MA. 1999. Improved survival of injured sciatic nerve Schwann cells in mice lacking the $\mathrm{p} 75$ receptor. Neurosci Lett 272: 191-194.

Fleck D, Garratt AN, Haass C, Willem M. 2012. BACE1 dependent neuregulin processing: Review. Curr Alzheimer Res 9: 178-183.

Fontana X, Hristova M, Da Costa C, Patodia S, Thei L, Makwana M, Spencer-Dene B, Latouche M, Mirsky R, Jessen KR, et al. 2012. c-Jun in Schwann cells promotes axonal regeneration and motoneuron survival via paracrine signaling. J Cell Biol 198: 127-141.

Fricker FR, Antunes-Martins A, Galino J, Paramsothy R, La Russa F, Perkins J, Goldberg R, Brelstaff J, Zhu N, McMahon SB, et al. 2013. Axonal neuregulin 1 is a rate limiting but not essential factor for nerve remyelination. Brain 136: $2279-2297$.

Friede RL, Bischhausen R. 1980. The fine structure of stumps of transected nerve fibers in subserial sections. $J$ Neurol Sci 44: 181-203.

Garratt AN, Britsch S, Birchmeier C. 2000. Neuregulin, a factor with many functions in the life of a Schwann cell. Bioessays 22: 987-996.

Grim M, Halata Z, Franz T. 1992. Schwann cells are not required for guidance of motor nerves in the hindlimb in Splotch mutant mouse embryos. Anat Embryol (Berl) 186: $311-318$. 
K.R. Jessen et al.

Grinspan JB, Marchionni MA, Reeves M, Coulaloglou M, Scherer SS. 1996. Axonal interactions regulate Schwann cell apoptosis in developing peripheral nerve: Neuregulin receptors and the role of neuregulins. J Neurosci 16: 6107-6118.

Harrisingh MC, Perez-Nadales E, Parkinson DB, Malcolm DS, Mudge AW, Lloyd AC. 2004. The Ras/Raf/ERK signalling pathway drives Schwann cell dedifferentiation. EMBO J 23: 3061-3071.

Hirata K, Kawabuchi M. 2002. Myelin phagocytosis by macrophages and nonmacrophages during Wallerian degeneration. Microsc Res Tech 57: 541-547.

Hoke A. 2006. Mechanisms of disease: What factors limit the success of peripheral nerve regeneration in humans? Nat Clin Pract Neurol 2: 448-454.

Hossain S, de la Cruz-Morcillo MA, Sanchez-Prieto R, Almazan G. 2012. Mitogen-activated protein kinase p38 regulates Krox-20 to direct Schwann cell differentiation and peripheral myelination. Glia 60: 1130-1144.

Hu X, Hicks CW, He W, Wong P, Macklin WB, Trapp BD, Yan R. 2006. Bace1 modulates myelination in the central and peripheral nervous system. Nat Neurosci 9: 1520-1525.

Jessen KR, Mirsky R. 2005. The origin and development of glial cells in peripheral nerves. Nat Rev Neurosci 6: 671682.

Jessen KR, Mirsky R. 2008. Negative regulation of myelination: Relevance for development, injury, and demyelinating disease. Glia 56: 1552-1565.

Jessen KR, Mirsky R. 2012. The Schwann cell lineage: Cellular transitions during development and after injury. In Neuroglia (ed. Kettenmann H, Ransom BR), pp. 159171. Oxford University Press, Oxford.

Joseph NM, Mukouyama YS, Mosher JT, Jaegle M, Crone SA, Dormand EL, Lee KF, Meijer D, Anderson DJ, Morrison SJ. 2004. Neural crest stem cells undergo multilineage differentiation in developing peripheral nerves to generate endoneurial fibroblasts in addition to Schwann cells. Development 131: 5599-5612.

Kaucká M, Adameyko I. 2013. Non-canonical functions of the peripheral nerve. Exp Cell Res 321: 17-24.

Keynes RJ. 1987. Schwann cells during neural development and regeneration: Leaders or followers. TINS 10: $137-$ 139.

Kim HA, Pomeroy SL, Whoriskey W, Pawlitzky I, Benowitz LI, Sicinski P, Stiles CD, Roberts TM. 2000. A developmentally regulated switch directs regenerative growth of Schwann cells through cyclin D1. Neuron 26: 405-416.

Kioussi C, Gross MK, Gruss P. 1995. Pax3: A paired domain gene as a regulator in PNS myelination. Neuron 15: $553-$ 562.

Kubu CJ, Orimoto K, Morrison SJ, Weinmaster G, Anderson DJ, Verdi JM. 2002. Developmental changes in Notch1 and numb expression mediated by local cell-cell interactions underlie progressively increasing delta sensitivity in neural crest stem cells. Dev Biol 244: 199-214.

La Marca R, Cerri F, Horiuchi K, Bachi A, Feltri ML, Wrabetz L, Blobel CP, Quattrini A, Salzer JL, Taveggia C. 2011. TACE (ADAM17) inhibits Schwann cell myelination. Nat Neurosci 14: 857-865.

Le N, Nagarajan R, Wang JY, Araki T, Schmidt RE, Milbrandt J. 2005. Analysis of congenital hypomyelinating Egr2 ${ }^{\mathrm{Lo} / \mathrm{Lo}}$ nerves identifies Sox 2 as an inhibitor of Schwann cell differentiation and myelination. Proc Natl Acad Sci 102: 2596-2601.

Lehmann HC, Hughes RA, Kieseler BC, Hartung HP. 2012. Recent developments and future directions in GuillainBarré syndrome. J Peripher Nerv Syst 17: 57-70.

Levi AD, Bunge RP, Lofgren JA, Meima L, Hefti F, Nikolics K, Sliwkowski MX. 1995. The influence of heregulins on human Schwann cell proliferation. J Neurosci 15: 13291340.

Lyons DA, Pogoda HM, Voas MG, Woods IG, Diamond B, Nix R, Arana N, Jacobs J, Talbot WS. 2005. erbb3 and erbb2 are essential for Schwann cell migration and myelination in zebrafish. Curr Biol 15: 513-524.

Mager GM, Ward RM, Srinivasan R, Jang SW, Wrabetz L, Svaren J. 2008. Active gene repression by the Egr2.NAB complex during peripheral nerve myelination. J Biol Chem 283: 18187-18197.

Martini R, Fischer S, López-Vales R, David S. 2008. Interactions between Schwann cells and macrophages in injury and inherited demyelinating disease. Glia 56: 15661577.

Meier C, Parmantier E, Brennan A, Mirsky R, Jessen KR. 1999. Developing Schwann cells acquire the ability to survive without axons by establishing an autocrine circuit involving insulin-like growth factor, neurotrophin-3 and platelet-derived growth factor-BB. J Neurosci 19: 38473859.

Meller K. 1987. Early structural changes in the axoplasmic cytoskeleton after axotomy studied by cryofixation. Cell Tissue Res 250: 663-672.

Merkle FT, Tramontin AD, García-Verdugo JM, AlvarezBuylla A. 2004. Radial glia give rise to adult neural stem cells in the subventricular zone. Proc Natl Acad Sci 101: 17528-17532.

Meyer D, Birchmeier C. 1995. Multiple essential functions of neuregulin in development. Nature 378: 386-390.

Mogha A, Benesh AE, Patra C, Engel FB, Schöneberg T, Liebscher I, Monk KR. 2013. Gpr126 functions in Schwann cells to control differentiation and myelination via G-protein activation. J Neurosci 33: 1797617985.

Morris JH, Hudson AR, Weddell G. 1972. A study of degeneration and regeneration in the divided rat sciatic nerve based on electron microscopy. Z Zellforsch Mikrosk Anat 124: $103-130$.

Morris JK, Lin W, Hauser C, Marchuk Y, Getman D, Lee KF. 1999. Rescue of the cardiac defect in ErbB2 mutant mice reveals essential roles of ErbB2 in peripheral nervous system development. Neuron 23: 273-283.

Napoli I, Noon LA, Ribeiro S, Kerai AP, Parrinello S, Rosenberg LH, Collins MJ, Harrisingh MC, White IJ, Woodhoo A, et al. 2012. A central role for the ERK-signaling pathway in controlling Schwann cell plasticity and peripheral nerve regeneration in vivo. Neuron 73: 729-742.

Nitzan E, Pfaltzgraff ER, Labosky PA, Kalcheim C. 2013. Neural crest and Schwann cell progenitor-derived melanocytes are two spatially segregated populations similarly regulated by Foxd3. Proc Natl Acad Sci 110: 1270912714 . 
Painter MW, Brosius Lutz A, Cheng YC, Latremoliere A, Duong K, Miller CM, Posada S, Cobos EJ, Zhang AX, Wagers AJ, et al. 2014. Diminished Schwann cell repair responses underlie age-associated impaired axonal regeneration. Neuron 83: 331-343.

Parkinson DB, Dong Z, Bunting H, Whitfield J, Meier C, Marie H, Mirsky R, Jessen KR. 2001. Transforming growth factor $\beta$ (TGF- $\beta$ ) mediates Schwann cell death in vitro and in vivo: Examination of c-Jun activation, interactions with survival signals, and the relationship of TGF- $\beta$-mediated death to Schwann cell differentiation. J Neurosci 21: 8572-8585.

Parkinson DB, Bhaskaran A, Arthur-Farraj P, Noon LA, Woodhoo A, Lloyd AC, Feltri ML, Wrabetz L, Behrens A, Mirsky R, et al. 2008. c-Jun is a negative regulator of myelination. J Cell Biol 181: 625-637.

Parrinello S, Napoli I, Ribeiro S, Wingfield Digby P, Fedorova $M$, Parkinson DB, Doddrell RD, Nakayama $M$, Adams RH, Lloyd AC. 2010. EphB signaling directs peripheral nerve regeneration through Sox2-dependent Schwann cell sorting. Cell 143: 145-155.

Raphael AR, Talbot WS. 2011 New insights into signaling during myelination in zebrafish. Curr Top Dev Biol 97: $1-19$.

Ribeiro S, Napoli I, White IJ, Parrinello S, Flanagan AM, Suter U, Parada LF, Lloyd AC. 2013. Injury signals cooperate with Nf1 loss to relieve the tumor-suppressive environment of adult peripheral nerve. Cell Rep 5: 126-136.

Ridley AJ, Davis JB, Stroobant P, Land H. 1989. Transforming growth factors- $\beta 1$ and $\beta 2$ are mitogens for rat Schwann cells. J Cell Biol 109: 3419-3424.

Rotshenker S. 2011. Wallerian degeneration: The innateimmune response to traumatic nerve injury. J Neuroinflamm 8: 109 .

* Salzer JL. 2015. Schwann cell myelination. Cold Spring Harb Perspect Biol doi: 10.1101/cshperspect.a020529.

Scherer SS, Wrabetz L. 2008. Molecular mechanisms of inherited demyelinating neuropathies. Glia 56: 1578-1589.

Shah NM, Marchionni MA, Isaacs I, Stroobant P, Anderson DJ. 1994. Glial growth factor restricts mammalian neural crest stem cells to a glial fate. Cell 77: 349-360.

Stewart HJ, Morgan L, Jessen KR, Mirsky R. 1993. Changes in DNA synthesis rate in the Schwann cell lineage in vivo are correlated with the precursor-Schwann cell transition and myelination. Eur J Neurosci 5: 1136-1144.

Stewart HJ, Brennan A, Rahman M, Zoidl G, Mitchell PJ, Jessen KR, Mirsky R. 2001. Developmental regulation and overexpression of the transcription factor $\mathrm{AP}-2$, a potential regulator of the timing of Schwann cell generation. Eur J Neurosci 14: 363-372.

Sulaiman OA, Gordon T. 2009. Role of chronic Schwann cell denervation in poor functional recovery after nerve injuries and experimental strategies to combat it. Neurosurgery 65: A105-A114.

Syroid DE, Maycox PJ, Soilu-Hänninen M, Petratos S, Bucci T, Burrola P, Murray S, Cheema S, Lee KF, Lemke G, et al. 2000. Induction of postnatal schwann cell death by the low-affinity neurotrophin receptor in vitro and after axotomy. J Neurosci 20: 5741-5747.

Vargas ME, Barres BA. 2007. Why is Wallerian degeneration in the CNS so slow? Annu Rev Neurosci 30: 153-179.

Vidal PM, Lemmens E, Dooley D, Hendrix S. 2013. The role of "anti-inflammatory" cytokines in axon regeneration. Cytokine Growth Factor Rev 24: 1-12.

Wanner IB, Guerra NK, Mahoney J, Kumar A, Wood PM, Mirsky R, Jessen KR. 2006a. Role of N-cadherin in Schwann cell precursors of growing nerves. Glia 54: 439-459.

Wanner IB, Mahoney J, Jessen KR, Wood PM, Bates M, Bunge MB. 2006b. Invariant mantling of growth cones by Schwann cell precursors characterize growing peripheral nerve fronts. Glia 54: 424-438.

Webber C, Zochodne D. 2010. The nerve regenerative microenvironment: Early behavior and partnership of axons and Schwann cells. Exp Neurol 223: 51-59.

Webster HD, Martin R, O'Connell MF. 1973. The relationships between interphase Schwann cells and axons before myelination: A quantitative electron microscopic study. Dev Biol 32: 401-416.

Witzel C, Rohde C, Brushart TM. 2005. Pathway sampling by regenerating peripheral axons. J Comp Neurol 485: $183-190$.

Woldeyesus MT, Britsch S, Riethmacher D, Xu L, Sonnenberg-Riethmacher E, Abou-Rebyeh F, Harvey R, Caroni P, Birchmeier C. 1999. Peripheral nervous system defects in erbB2 mutants following genetic rescue of heart development. Genes Dev 13: 2538-2548.

Wolpowitz D, Mason TB, Dietrich P, Mendelsohn M, Talmage DA, Role LW. 2000. Cysteine-rich domain isoforms of the neuregulin-1 gene are required for maintenance of peripheral synapses. Neuron 25: 79-91.

Woodhoo A, Sommer L. 2008. Development of the Schwann cell lineage: From the neural crest to the myelinated nerve. Glia 56: 1481-1490.

Woodhoo A, Alonso MB, Droggiti A, Turmaine M, D’Antonio M, Parkinson DB, Wilton DK, Al-Shawi R, Simons P, Shen J, et al. 2009. Notch controls embryonic Schwann cell differentiation, postnatal myelination and adult plasticity. Nat Neurosci 12: 839-847.

Yang DP, Zhang DP, Mak KS, Bonder DE, Pomeroy SL, Kim HA. 2008. Schwann cell proliferation during Wallerian degeneration is not necessary for regeneration and remyelination of the peripheral nerves: Axon-dependent removal of newly generated Schwann cells by apoptosis. Mol Cell Neurosci 38: 80-88.

Yang DP, Kim J, Syed N, Tung YJ, Bhaskaran A, Mindos T, Mirsky R, Jessen KR, Maurel P, Parkinson DB, et al. 2012. p38 MAPK activation promotes denervated Schwann cell phenotype and functions as a negative regulator of Schwann cell differentiation and myelination. J Neurosci 32: $7158-7168$.

Yu WM, Feltri ML, Wrabetz L, Strickland S, Chen ZL. 2005. Schwann cell-specific ablation of laminin $\gamma 1$ causes apoptosis and prevents proliferation. J Neurosci 25: 4463-4472. 


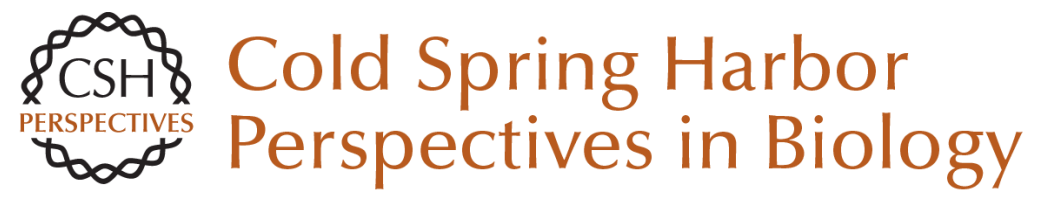

\section{Schwann Cells: Development and Role in Nerve Repair}

Kristján R. Jessen, Rhona Mirsky and Alison C. Lloyd

Cold Spring Harb Perspect Biol 2015; doi: 10.1101/cshperspect.a020487 originally published online May 8, 2015

\section{Subject Collection Glia}

The Nodes of Ranvier: Molecular Assembly and Maintenance

Matthew N. Rasband and Elior Peles

Microglia in Health and Disease

Richard M. Ransohoff and Joseph El Khoury

The Astrocyte: Powerhouse and Recycling Center Bruno Weber and L. Felipe Barros

Microglia Function in Central Nervous System

Development and Plasticity

Dorothy P. Schafer and Beth Stevens

Transcriptional and Epigenetic Regulation of Oligodendrocyte Development and Myelination in the Central Nervous System

Ben Emery and Q. Richard Lu

Origin of Microglia: Current Concepts and Past

Controversies

Florent Ginhoux and Marco Prinz

Glia Disease and Repair--Remyelination

Robin J.M. Franklin and Steven A. Goldman

Astrocytes in Neurodegenerative Disease

Hemali Phatnani and Tom Maniatis
Oligodendrocyte Development and Plasticity Dwight E. Bergles and William D. Richardson

Oligodendrocytes: Myelination and Axonal

Support Mikael Simons and Klaus-Armin Nave

Drosophila Central Nervous System Glia Marc R. Freeman

Perisynaptic Schwann Cells at the Neuromuscular

Synapse: Adaptable, Multitasking Glial Cells Chien-Ping Ko and Richard Robitaille

Astrocytes Control Synapse Formation, Function, and Elimination Won-Suk Chung, Nicola J. Allen and Cagla Eroglu

Schwann Cell Myelination James L. Salzer

Schwann Cells: Development and Role in Nerve Repair

Kristján R. Jessen, Rhona Mirsky and Alison C. Lloyd

Perineurial Glia

Sarah Kucenas

For additional articles in this collection, see http://cshperspectives.cshlp.org/cgi/collection/

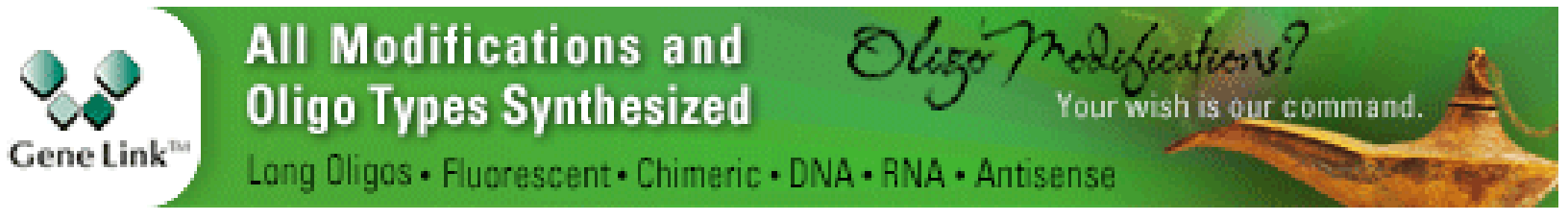

Copyright @ 2015 Cold Spring Harbor Laboratory Press; all rights reserved 